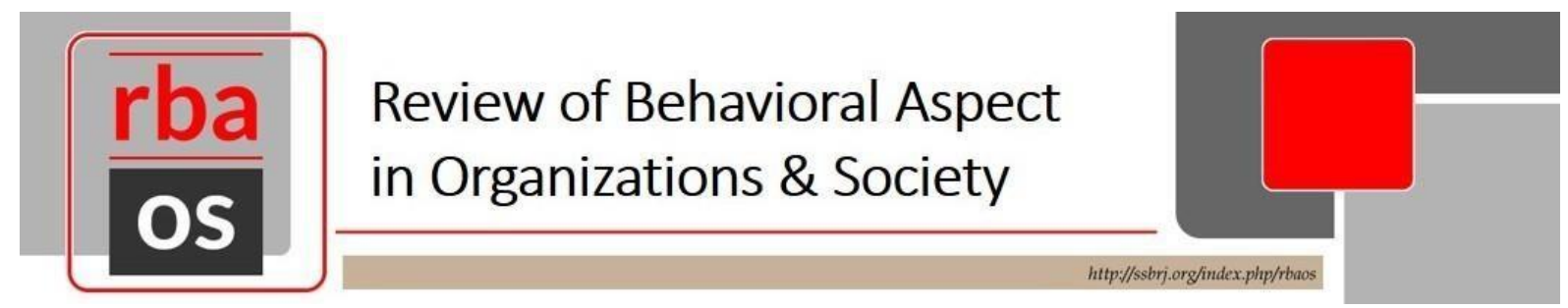

\title{
DEVELOPING INSTAGRAM FILTER-BASED ACCOUNTING EDUCATIONAL GAME AS A FUN LEARNING MEDIA
}

\author{
Frandy E.F. Karundeng, Universitas Pelita Harapan, Indonesia
}

\begin{abstract}
The learning process in accounting courses often becomes boring and even intimidating for students because the material is often considered difficult or involves a lot of calculations that the learning situation becomes rigid and students cannot enjoy the learning process. For this reason, lecturers must prepare an alternative media for learning that is more interesting, for example by using games. The game in this research is based on the Instagram filter as most students have an Instagram account and spend a lot of time on that photo-sharing platform. The game was developed using the ADDIE model (Analysis, Design, Development, Implementation, and Evaluation). In the development stage, this game was validated by material expert and information technology expert, and was then implemented to 100 accounting students. Based on the evaluation results, this game was declared to be very feasible in terms of software, display, and learning design aspects. Moreover, this Instagram filter-based accounting educational game was declared a fun learning media for students, and was able to motivate students to study accounting as indicated by the average total score of 4.48 or "very high" for the learning motivation aspect.

Keywords: education game, accounting, Instagram filter, fun learning, debit-credit
\end{abstract}




\section{Introduction}

At present, the world of education is required to continuously make adjustments and adapt information technology to the education system so that it is always able to provide education that is in line with the development and needs of students and does not lag behind the development of global education (Yana, Komara, \& Anisah, 2019). The challenge facing the world of education today is the application of information technology to the teaching-learning process. Information technology has indeed been adapted in the teaching-learning process but has not yet made a significant difference in how material is taught (Pincus, Stout, Sorensen, Stock, \& Lawson, 2017). Even Bill Gates, in October 2013, in the Association of Community College Trustees' activities, said that "As someone passionate about technology, I've been frustrated to see how little technology has changed the way we teach our students" (Pincus et al., 2017 ). Therefore, lecturers or educators play a very important role in the application of information technology in the teaching-learning process.

Lecturers must think creatively in preparing an interesting and technology-based learning media in order to create a pleasant learning atmosphere, to increase student motivation, and ultimately, it is expected to increase student competences (Yana et al., 2019). According to Seow and Wong (2016), accounting courses are subjects that are considered by most people to be difficult, uninteresting, and even boring. Hence, it is very important to develop an interesting and enjoyable learning media in the process of teaching courses in accounting study program, for example courses of principle of accounting, financial accounting, and management accounting.

In general, people will learn things better when they like what they are learning (Seow \& Wong, 2016). Thus, interesting learning media can help students to understand the material taught by lecturers (Hikmah \& Mustikawati, 2017). Students can learn more things while playing games (Li, Ma, \& Ma, 2012). Games have strengths in the process of teaching, training, educating, and are very effective in shaping skills and behavior, one thing that is difficult to do by memorization (Michael and Chen (2006) in Vandercruysse, Vandewaetere, \& Clarebout, 2012). Therefore, information technology-based educational games can be an interesting and fun learning medium that makes people feel challenged to master it, and even causes an addiction (Yana et al., 2019). Furthermore, according to Calabor, Mora, and Moya (2018), learning media based on educational games can create a more active learning process and motivate students to learn. So, accounting lecturers can use games as an interesting and fun learning media to minimize the boredom problems that often experienced by their students.

Games as learning media can be developed on social media platforms. Internet users spend a lot of time using social media. Based on GlobalWebIndex data, in 2019, the average time spent by one person on social media is 143 minutes per day or up to 14 hours per week (Duarte, 2019). According to data published by Kepios Analysis, the worldwide number of user accounts of 15 social media platforms in January 2020 reached 12.8 billion. From this data, the number of accounts from the Instagram platform reached 1 billion (Ramadhan, 2020). Instagram users in Indonesia in November 2019 according to data published by NapoleonCat reached 6.6 million accounts. From the data the most number of users, around $37.3 \%$ or as many as 23 million users, were in the age range of 18-24 years or the age of college students ("Is This The Number of Instagram," 2019). Moreover, according to Amy, Carter and Shuo (2019), young people tended to use social media in their daily social group interactions, hence social media can be the potent force to reach and build communication with and within millennial groups. Lecturers can take advantage of this opportunity by innovating to develop 
an Instagram platform-based educational game as an interesting and fun learning media for the students.

Instagram is a social media platform that is growing rapidly (Former, 2010 in Sheldon \& Bryant, 2016). Instagram was initially developed as a social media site that enabled people to share photos and videos using hashtags to make it easier for users to find photos and videos. Instagram has special features such as Instagram filters that allow users to change the color and resolution of photos before they share them on their homepage or in their account stories (Lunden, 2014 in Sheldon \& Bryant, 2016). Instagram has developed the function of filter; besides changing the color of the photo, the filter feature can also bring Augmented Reality (AR). Augmented Reality is a direct or indirect visualization of the real world which is then enlivened with digital or virtual content created by computers. Users can see digital content in the real world in three dimensions (Carmigniani et al., 2011). This AR Instagram filter is very popular with users because it looks interesting and fun to play.

Through the Spark AR application, which was launched in August 2019, anyone can create AR filters for free and share them with all Instagram users. This opportunity can be used by lecturers to develop an educational game that can be played more often by students. Users do not need to download additional applications to play this Instagram filter-based game. They only need to search for the filter name and directly play it. In addition, this game can be recorded and immediately shared on users' Instagram stories.

Based on the results of research conducted by Sheldon and Bryant (2015), the motive of people using Instagram is to look cool. Instagram users will try to look their best on Instagram in order to get recognition through likes, comments, and views of shared photos or videos. Furthermore, Sheldon and Bryant (2015) concluded that this motive has a negative relationship with life satisfaction, due to social pressure to look cool. With this Instagram filter-based game, users are expected to try to look smart by repeatedly playing the game until they succeed and share it to their Instagram account so that it can be seen by many people. This certainly can trigger student interest in mastering the material in the Instagram filter-based game.

Instagram filter-based accounting education game is a creative idea in developing a fun learning media. The combination of game-based learning media and social media has great potential to be played by students so they can be more familiar with the learning material. Instagram filter based games really allow students to study anywhere and anytime in a more fun way. Facer et al, (2004) in Seow and Wong (2016) said that the high participation and motivation of students in playing games will have an impact on the improvement of learning outcomes. Thus, this research will develop an accounting education game based on the Instagram filter as an interesting and fun learning media so that students are no longer bored but are increasingly motivated to study accounting.

Based on the aforementioned background, this study aims to develop an Instagram filter-based accounting educational game as fun learning media. Then, determine the game feasibility based on the validation results from accounting material expert and information technology expert. Finally, this study determines the student interest and level of learning motivation with this Instagram filter-based accounting education game. The limitation of the problem in this study is related to accounting learning materials used in the games. The learning material used is in accordance with the Semester Learning Design (RPS) in financial accounting 1, which is about double-entry accounting systems (debit and credit) and journal entry of transactions at service company. 


\section{Literature Review}

\section{Learning Media}

The media is a transmission of all technology used to record information and send it to other parties (Saputri, et al, 2020). Learning media includes all things that can be used to channel content from instructors to students by stimulating students' thoughts, feelings, and abilities so that the teaching-learning process can be improved (Ibrahim \&Syaodih, 2013, in Saputri, et al, 2020). Mardikaningrum, et al (2017) say that learning media is an important component that determines the success of the learning process.

\section{Educational Game}

Educational game according to Novaliendry (2013) in Utami and Putri (2019) is a game deliberately designed for educational purposes. Through educational games students are expected to be more active and more quickly understand the learning material. The use of educational games in higher education institutions can be in the form of digital game-based learning (DGBL), applied games, video games, web-based games, and technological platforms (Vlachopoulos\&Makri, 2017).

\section{Fun Learning Media}

Fun learning media is the powerful tool to create an interactive learning and to engage students with the learning process (Charsky \& Ressler, 2010). Fun learning is described as when the student can be attracted to the learning process (Carrol, 2004 in Rambli, Matcha, \& Sulaiman, 2013). According to Malone and Lapper (1982) in Rambli, Matcha, and Sulaiman (2013), fun is associated with motivation. Hence, fun learning media is the media in learning process that can increase students motivation in engaging with the learning process.

\section{Instagram Platform}

Instagram is a social media platform founded by Kevin Systrom and Mike Grieger in 2010. It is a mobile application for smartphones that can be downloaded for free on the App. Store and Google Play Store (Bergstorm \& Backman, 2013 in Ting, Ming, Run, \& Choo, 2015). Instagram, which is basically a photo and video sharing application, has now developed into a social media platform, that most often used by both individuals and companies in communication and marketing (Ting et al., 2015). Features owned by Instagram include stories, direct messages, IGTV, search and explore, and shopping. In the stories feature, users can use various Instagram filter options. This feature allows users to edit photos or videos so they look more interesting before being shared on Instagram stories. Instagram filters have become more interesting since the launch of the Augmented Reality (AR) application, Spark AR in 2019. Spark AR is a free application for creating AR and can be shared as an Instagram filter.

\section{Accounting in Service Company}

Accounting consists of three basic activities, namely identifying, recording, and communicating economic events from an organization to other parties who need the information (Weygandt, et al, 2015). In accounting there are three types of profit-oriented businesses, namely service, merchandising, and manufacturing business. Service companies are companies that sell services instead of products to customers (Warren, Reeve, \& Duchac, 2009). The basic equation in Accounting is Assets = Liabilities + Owner's Equity. Debit (Dr.) and Credit (Cr.) describe where the record will be entered in the account. The double-entry system is the basis for recording that a debit transaction must be the same as a credit transaction (Weygandt, Kimmel, \& Kieso, 2015). 


\section{Research Method}

Types of Research

This research is a type of Research and Development (R\&D). Research and Development research is a research method used to develop a particular product and to test the validity and effectiveness of the product (Sugiyono, 2017). According to Grafinger (1988) in Molenda (2015), R\&D research uses the ADDIE model (Analysis, Design, Development, Implementation, and Evaluation). ADDIE is the main model that is often used in the development of an organization.

\section{Research Subjects and Objects}

Subjects in this study were students of accounting study program who had attended the financial/principle accounting 1 course and two validators consisting of one information and technology expert (lecturer in the Faculty of Information and Technology) and one Accounting material expert (lecturer in Accounting study program). The object of this research was the development of accounting educational game based on Instagram filter.

\section{Data Collection Techniques}

Data collection in this study was carried out by distributing questionnaires to 100 accounting students and validation sheets to two experts. The questionnaires was distributed online using Microsoft Forms. Questionnaire indicators used in this study can be seen in Table 1.

Table 1. Questionnaire Indicators

\begin{tabular}{lll}
\hline No & \multicolumn{1}{c}{ Validator } & \multicolumn{1}{c}{ Indicator } \\
\hline \multirow{2}{*}{1} & \multirow{2}{*}{ Material Expert } & 1. Relevance \\
& & 2. Material accuracy \\
& & 3. Questions \\
& & 4. Language \\
\hline \multirow{2}{*}{2} & \multirow{2}{*}{ Information } & 1. Display \\
& Technology Expert & 2. Visual communication \\
& & 3. Software \\
\hline \multirow{3}{*}{3} & College student & 1. Software \\
& & 2. Display \\
& & 3. Learning design \\
& & 4. Learning motivation \\
\hline
\end{tabular}

Source: Processed data, 2020.

Questionnaire data were measured using a Likert scale (Sugiyono, 2017). Questionnaire scoring based on Likert scale can be seen in Table 2 .

Table 2. Questionnaire Scoring

\begin{tabular}{cc}
\hline Score & Definition \\
\hline 5 & Strongly Agree \\
4 & Agree \\
3 & Undecided \\
2 & Slightly Disagree \\
1 & Disagree \\
\hline
\end{tabular}

Source: Processed data, 2020. 


\section{Data Analysis Methods}

Qualitative data were analyzed by systematically compiling the obtained data and developing it into each process of the research stages to become a final product, i.e. the game. Quantitative data analysis method used to analyze the results of the validation of experts was by calculating the average score of each indicator and converting it into qualifications at class intervals (Table 3.3 ), until it can be qualitatively analyzed in the form of explanations. The average score formula used was:

$X=\frac{\sum x}{N}$

Definition:

$\mathrm{X}=$ Average score

$x=$ Total score

$\mathrm{N}=$ Number of questions

(Widyoko, 211: 236, in Pratiwi \& Sagoro, 2017)

Student questionnaire results were analyzed using descriptive statistical techniques. Descriptive statistical data analysis was carried out to provide conclusions about the collected answers of respondents (Sugiyono, 2017). The respondents' answers on each indicator were then categorized based on class intervals. This categorization was done to find out the description of respondents' answers on the feasibility of the product. The categorization of class intervals is shown in Table 3.

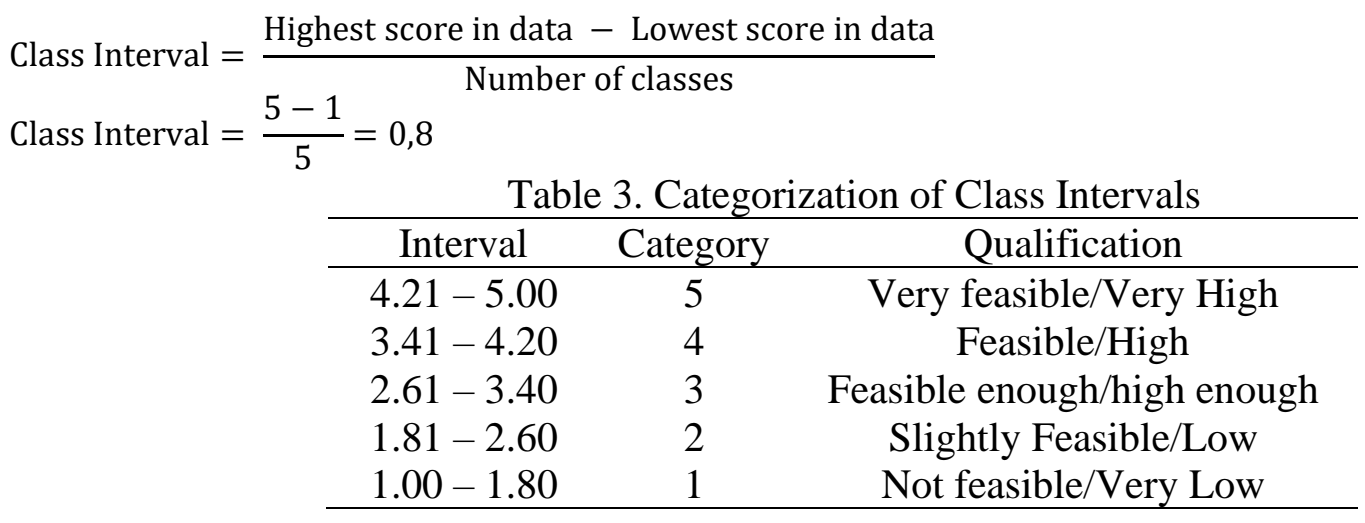

In this study data quality testing was also carried out through validity and reliability tests. Validity test was used to measure the validity of a questionnaire based on the corrected itemtotal correlation value. Questionnaire is valid if $r$ is positive and is greater than the $r_{\text {table. The }}$ reliability test was then performed to measure the consistency of the respondents' answers. The questionnaire is reliable if the Cronbach's Alpha value $>0.60$ (Sunyoto, 2016). This research was analyzed in five stages as in the ADDIE model. The stages of the research is shown in Figure 1. 


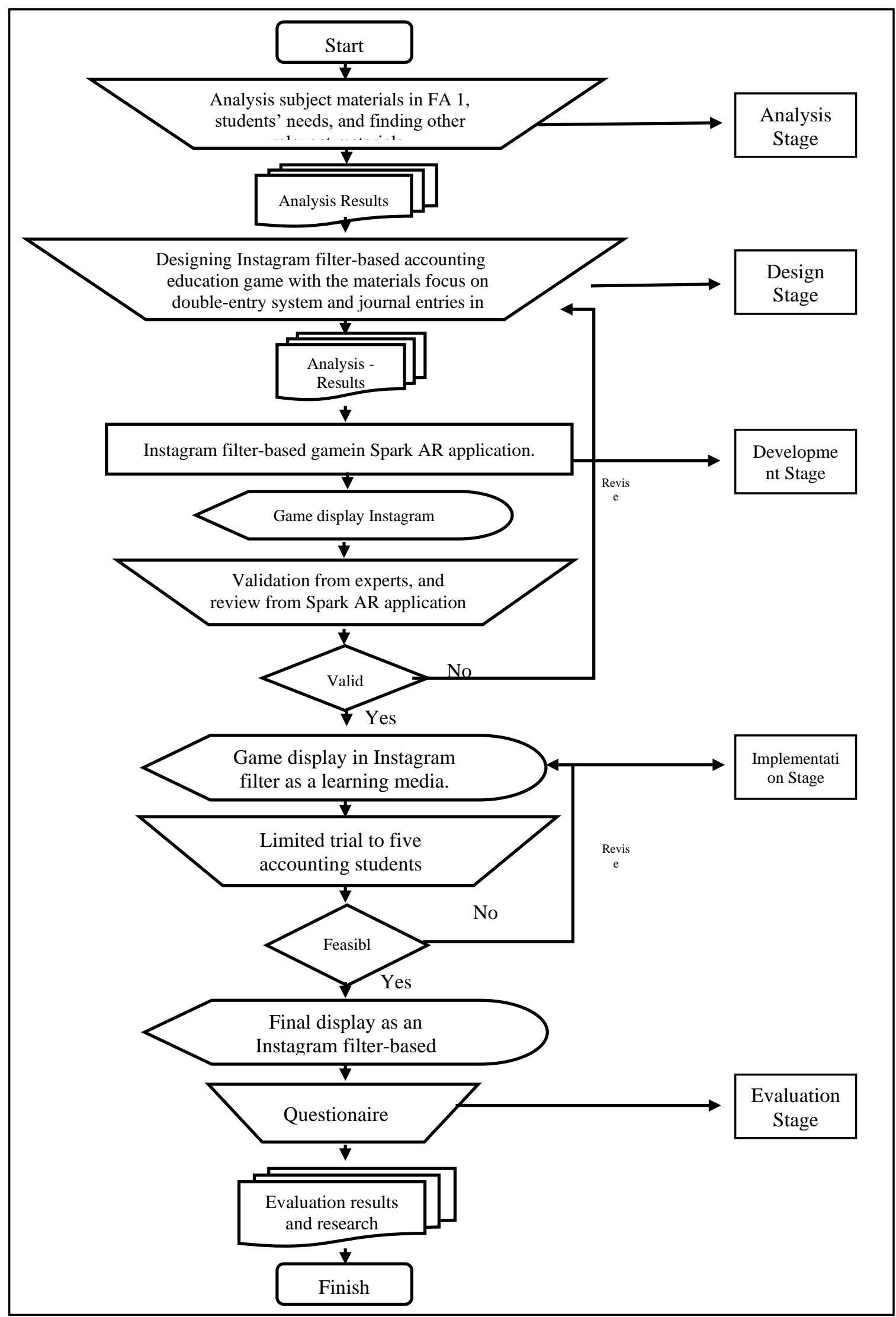

Source: Processed data, 2020

Figur 1. Stages in ADDIE Model. 


\section{Result and Discussion}

Instagram filter-based accounting educational game as a fun learning media is developed based on the stages of the development of the ADDIE model, namely Analysis, Design, Development, Implementation, and Evaluation.

\section{Analysis Stage}

At this stage an analysis of student needs in the learning process of accounting courses was carried out. Based on the results of the initial interviews with accounting students, it was found that the problems that were often experienced by students that caused boredom in the learning process were related to the learning media used by lecturers. The average use of accounting teaching media by lecturers was limited to slide presentations or learning videos taken from other sources. The students said that the atmosphere of learning in accounting subjects was less pleasant compared to other subjects. According to the students, accounting is a subject that is quite difficult and requires more concentration. This causes students to become very serious or rigid in the classroom so that the learning atmosphere becomes unpleasant. This atmosphere will be more boring and even tends to be intimidating if the learning media used by lecturers cannot melt the atmosphere or excite students to learn.

Therefore, a solution is needed to increase student motivation in Accounting courses. In this research, a creative and innovative learning media will be developed as a solution. Through fun learning media, students are expected to be more interested and eager to learn accounting. The next step is to look for various references relating to the development plan of an interesting accounting learning media based on Instagram filter. References can be sourced from previous research journals, books, news, and other valid sources related to the development of educational games.

\section{Design Stage}

At this stage the architecture design of the Instagram filter-based accounting education game was carried out. The design made at this stage includes: (a) determining game play or interaction between players and the game world; (b) compiling questions and answers; (d) collecting and making backgrounds for questions and answers, and also the music and sound effects. The game play can be seen in Table 4 .

Table 4. Game Play

\begin{tabular}{cl}
\hline No. & \multicolumn{1}{c}{ Action } \\
\hline 1 & User searches for filters on Instagram with the title "Debit or Credit", or types in \\
& some related words, such as accounting and journal entries. \\
2 & The intro and music page appear on the Instagram story. \\
3 & User presses and holds the 'record button' or presses the hands-free button on \\
& Instagram to start the game. \\
4 & The game is displayed. \\
5 & The intro page re-appears for two seconds. \\
6 & The first question appears and must be answered within five seconds (questions \\
& $\begin{array}{l}\text { appear randomly for different users). } \\
7\end{array}$ \\
& User answers by moving his/her head to the right to choose the answer 'credit', and to \\
8 & Incorrect or correct answers will be seen from the display animation and sound \\
& effects.
\end{tabular}


9 After the answer is displayed, the next question and answer will appear. In one game, three questions and answers will appear in a row.

10 After user answers three questions, a closing page and sound effects will appear.

11 User can directly publish the results on Instagram stories or download and save them in the mobile storage.

Source: Processed data, 2020.

The questions are arranged based on the Semester Learning Design (RPS) of financial accounting 1 . The questions relate to the material of double-entry accounting system or DebitCredit system in service company. The Debit-Credit System in the questions includes transactions in general journals, adjusting journals, and closing journal entries. Questions and answers are in English and in accordance with international IFRS (International Financial Reporting Standards) and also consist of 24 questions with two variations. Table 5 shows Examples of questions and answers, then Figure 2 shows the background image of questions and answers.

Table 5. Examples of Questions and Answers

\begin{tabular}{clc}
\hline No. & \multicolumn{1}{c}{ Questions } & Answers \\
\hline 1 & Decrease in Cash & Debit \\
2 & Received cash from owner. Owner's capital is in ... & Credit \\
\hline
\end{tabular}

Source: Processed data, 2020.

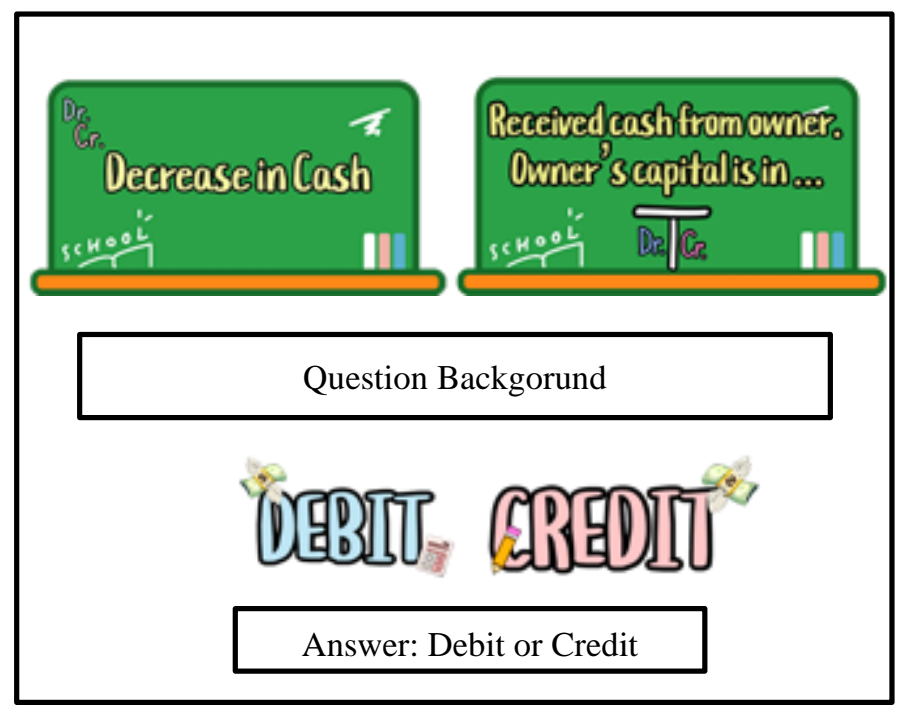

Source: Processed data, 2020

Figure 2. Background Image of Questions and Answers

\section{Development Stage}

At this stage an Instagram filter based accounting education game was made using the Spark AR application. This stage included three activities, creating a user interface, creating a patch editor and coding in the Spark AR application, and validation by material and information technology experts. After completing the Spark AR application, the Instagram filter was sent to the Spark AR developer for review before being approved as a filter on Instagram. A review by Spark AR was carried out to ensure that the content in the filter complied with the specified standards. This filter reviewtook one day. User interface of the Instagram filter-based accounting educational game is shown in Figure 3. 


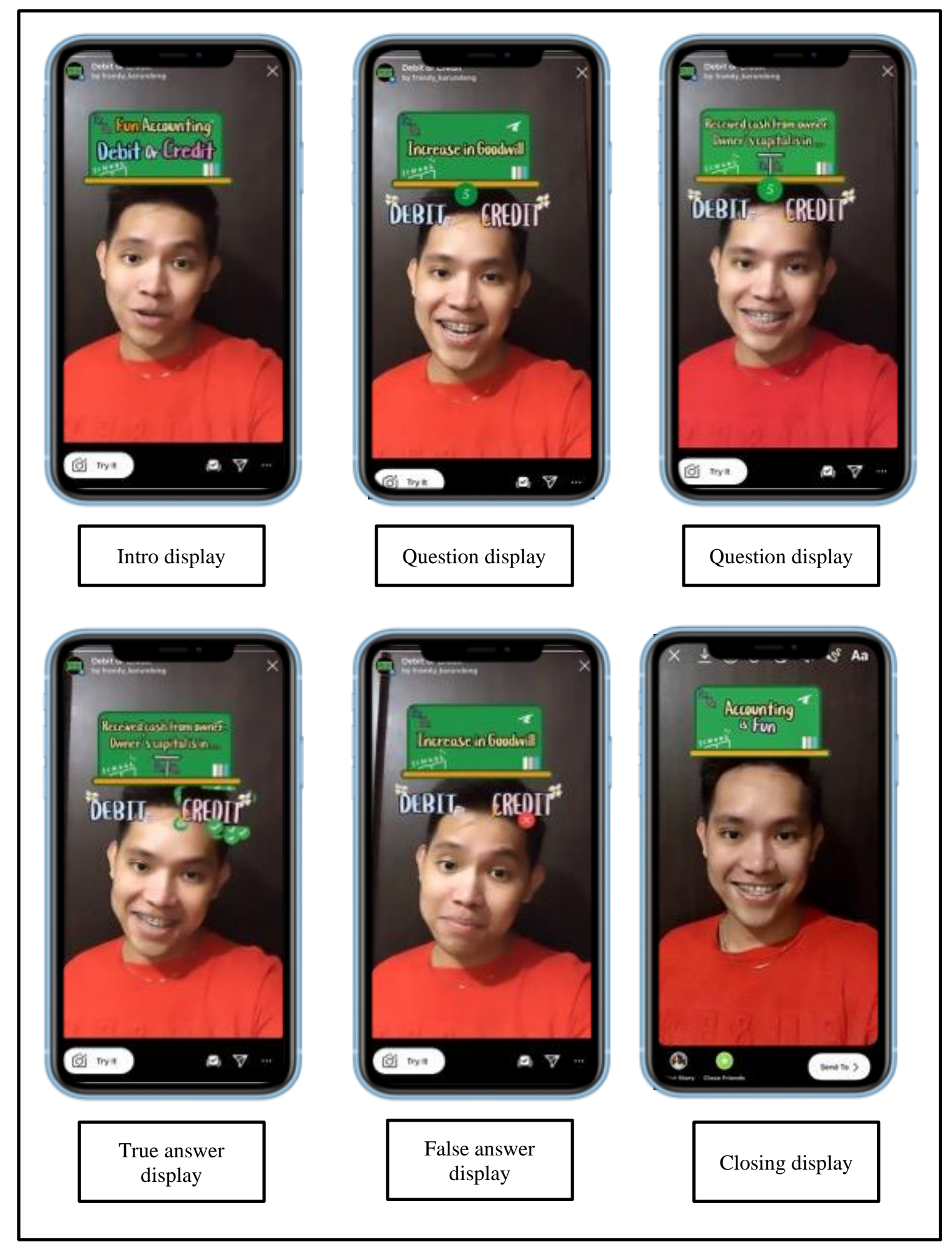

Source: Processed data, 2020.

Figure 3. User interface of the Instagram Filter-Based Accounting Educational Game

Afterwards, an analysis of the validation by material and information technology experts was carried out. This was done to assess the feasibility of instructional media, both in terms of 
material and information technology. The higher the validation rate from the experts, the higher the level of feasibility of the Instagram filter-based accounting educational game. Validation was carried out by two validators. The validation of accounting material was carried out by a Lecturer in the Accounting Study Program at Prisma University who also teaches Financial Accounting Courses. Information technology media validation was carried out by a Lecturer in Information Systems Study Program at Ciputra University who has expertise in Human Computer Interaction (UX/UI Design). The results of validation by the material and information technology experts can be seen in Table 6 and Table 7, respectively.

Table 6. Validation Results of Material Expert

\begin{tabular}{|c|c|c|c|}
\hline No. & Aspect & Average Score & Qualification \\
\hline 1 & Relevance & 4.50 & Very Feasible \\
\hline 2 & Material accuracy & 5.00 & Very Feasible \\
\hline 3 & Questions & 4.33 & Very Feasible \\
\hline 4 & Language & 5.00 & Very Feasible \\
\hline & Average total score & 4.71 & Very Feasible \\
\hline
\end{tabular}

Source: Processed data, 2020.

Table 7. Validation Results of Information Technology Expert

\begin{tabular}{clcl}
\hline No. & \multicolumn{1}{c}{ Aspect } & Average Score & Qualification \\
\hline 1 & Display & 4.55 & Very Feasible \\
2 & Visual communication & 4.50 & Very Feasible \\
3 & Software & 4.00 & Feasible \\
& Average total score & $\mathbf{4 . 3 5}$ & Very Feasible \\
\hline
\end{tabular}

Source: Processed data, 2020.

The results of the material expert validation in Table 6 show that all aspects of the material, namely the relevance, accuracy of the material, questions, and language are very feasible because all average scores are in the interval 4.21 - 5.00. The average total score shows 4.71, which means that based on all aspects of the material, it is very feasible to develop and implement this game. The results of information technology expert validation in Table 7 also show the average total score is in the range of $4.21-5.00$, which is 4.35 . Thus, the information technology expert also states that based on the aspects of appearance, visual communication, and software, it is very feasible to implement the game.

Based on the results of the validation of the two validators, both in terms of material and information technology, Instagram filter-based accounting educational game as a fun learning media is valid and feasible to be implemented. Improvements made based on input from information technology experts are related to video tutorials on game use and image sizes that should be enlarged. Further improvements were made according to the advice of information technology experts. After being declared valid by experts, the Instagram filter was submitted to the Spark AR application developer for review before being approved as a filter on the Instagram platform.

\section{Implementation Stage}

At this stage, the Instagram filter-based accounting educational game had been approved by the Spark AR application developer and was ready for testing. This filter was reviewed by Spark AR for one day and approved. The first step in the implementation phase was a limited trial on five accounting students. The trial results were analyzed based on the student answers in the questionnaire. The results of limited trials can be seen in Table 8 . 
Table 8. Limited Trial Results

\begin{tabular}{clcl}
\hline No. & \multicolumn{1}{c}{ Aspect } & Average Score & Qualification \\
\hline 1 & Software & 4.84 & Very Feasible \\
2 & Display & 4.84 & Very Feasible \\
3 & Learning design & 4.95 & Very Feasible \\
4 & Learning motivation & 4.75 & Very Feasible \\
& Average total score & $\mathbf{4 . 8 5}$ & Very Feasible \\
\hline
\end{tabular}

Source: Processed data, 2020.

Table 8. shows that the average scores of all aspects assessed, including software, display, learning design, and learning motivation, were all at intervals of $4.21-5.00$ or met the 'very feasible' qualification. The average score of 4.84 also shows that overall this game can be implemented to students widely because it is categorized in the 'very feasible' qualification.

After the game was declared feasible in a limited trial, the final step was to implement it to accounting students widely. The spread of Instagram filter based game was done by snow ball technique, where the games was spread through a rolling process from one user to another in one network (Sugiyono, 2017). Initially this Instagram filter was uploaded to the one's Instagram account stories, then promoted to all accounting students who follow the that Instagram account. Furthermore, this Instagram filter will spread widely through Instagram accounts that upload it to their Instagram stories. Instagram filter-based accounting educational game as an interesting learning media can be accessed via the link below: https://www.instagram.com/ar/253706675967507/.

\section{Evaluation Stage}

At this stage an evaluation of Instagram filter-based game implementation to accounting students is carried out. The evaluation is based on the results of questionnaires distributed to 100 respondents who are accounting students and have taken the financial/principle accounting 1 course.

\section{Data Quality Testing through Validity and Reliability Tests}

The results of the data quality testing based on the validity test using the SPSS 22.0 statistical application showed that all $r_{\text {count }}$ values were greater than $r_{\text {table }}$ values, or were greater than 0.1966 . Thus, it can be concluded that the questionnaire is valid or can be used to measure the feasibility of an Instagram filter-based educational game from the perspective of accounting students. The results of the validity test can be seen in Table 9.

A reliability test was then carried out to measure the consistency of the respondents' answers. The results show that the Cronbach's Alpha value of 18 statements in the questionnaire was 0.939. Because the Cronbach's Alpha value was positive and greater than 0.60 , it can be concluded that the respondents' answers to all statements in the questionnaire were reliable or consistent. The reliability test data can be seen in Table 10 .

\section{Descriptive Statistics}

A descriptive statistics test was carried out to find the average score of respondents' answers on each aspect of this Instagram filter-based game. The average score of these answers would be entered into class intervals to assess the feasibility of the game in terms of software, display, 
learning design, and learning motivation. Descriptive statistical test results using SPSS 22.0 for each aspect can be seen in Table 11 - Table 14.

Table 9. Validity Test Results

\begin{tabular}{|c|c|c|c|}
\hline No & Statement in the Questionnaire & $\begin{array}{c}\text { Pearson } \\
\text { Correlation } \\
\text { Value with } \\
\text { Total Score } \\
\left(\mathbf{r}_{\text {table }}=\right. \\
\mathbf{0 . 1 9 6})\end{array}$ & Definition \\
\hline 1 & $\begin{array}{l}\text { The game filter can be found easily on the Instagram } \\
\text { platform }\end{array}$ & 0.544 & Valid \\
\hline 2 & The game can be played easily & 0.634 & Valid \\
\hline 3 & $\begin{array}{l}\text { The game operates smoothly (does not freeze or stop when } \\
\text { played) }\end{array}$ & 0.665 & Valid \\
\hline 4 & Visual effects function properly & 0.746 & Valid \\
\hline 5 & The game can be run on various smartphone specifications & 0.660 & Valid \\
\hline 6 & The game display is attractive & 0.741 & Valid \\
\hline 7 & The image is clear and has a proportional size & 0.835 & Valid \\
\hline 8 & The writing can be read clearly & 0.790 & Valid \\
\hline 9 & The sound effects and music used are interesting & 0.743 & Valid \\
\hline 10 & The face mesh effect (smoother facial skin) is useful & 0.555 & Valid \\
\hline 11 & The language used is communicative & 0.695 & Valid \\
\hline 12 & $\begin{array}{l}\text { The language used is in accordance with the student } \\
\text { competence }\end{array}$ & 0.723 & Valid \\
\hline 13 & $\begin{array}{l}\text { The questions are in accordance with financial accounting } \\
1 \text { learning material, which is the double-entry system (Dr. } \\
\text { and Cr.) }\end{array}$ & 0.760 & Valid \\
\hline 14 & Questions are presented clearly and interestingly & 0.819 & Valid \\
\hline 15 & This game makes me interested to play it again & 0.689 & Valid \\
\hline 16 & This game makes me happy to learn accounting & 0.717 & Valid \\
\hline 17 & $\begin{array}{l}\text { This game makes me more interested in learning an } \\
\text { accounting material }\end{array}$ & 0.734 & Valid \\
\hline 18 & This game motivates me to study accounting & 0.714 & Valid \\
\hline
\end{tabular}

Source: Data processed with SPSS, 2020.

\begin{tabular}{|}
\begin{tabular}{|cc|}
\hline \multicolumn{2}{|c|}{ Table 10. Reliability Test Results } \\
\hline Cronbach's Alpha & N of Items \\
\hline 0.939 & 18 \\
\hline
\end{tabular} Source: Data processed with SPSS, 2020.
\end{tabular}

Based on the data in Table 11, it can be concluded that judging from the software aspect, this Instagram filter-based game can be categorized as 'very feasible' to use. There are two indicators that get the average score in the interval of $3.41-4.20$, namely statements number one and three. However, because it is still in the feasible category, there is no significant evaluation. Basically, to find this game is very easy; the user simply presses the filter title on another account's Instagram stories and the user can directly use it. Difficulties may appear when searching for the filter title when the filter is not displayed on another account's Instagram story. If so, then the user must go to the search menu in the Instagram filter and type in the 
filter title or word related to the filter, for example the words accounting, debit, credit, journal, or entry, and the filter will immediately appear in the search page. Statement number two regarding the smooth operation of the game also gets the 'feasible' qualification with an average value of 4.17. This is very dependent on the quality of the user's internet network, where a slow internet connection can cause Instagram filters to take a long time to load.

Table 11. Results of the Descriptive Statistics Test on Software Aspect

\begin{tabular}{|c|c|c|c|}
\hline No. & $\begin{array}{l}\text { Software Aspect } \\
\end{array}$ & Average Score & Qualification \\
\hline 1 & $\begin{array}{l}\text { The game filter can be found easily on the } \\
\text { Instagram platform }\end{array}$ & 4.19 & Feasible \\
\hline 2 & The game can be played easily & 4.39 & Very Feasible \\
\hline 3 & $\begin{array}{l}\text { The game operates smoothly (does not freeze } \\
\text { or stop when played) }\end{array}$ & 4.17 & Feasible \\
\hline 4 & Visual effects function properly & 4.33 & Very Feasible \\
\hline \multirow[t]{2}{*}{5} & The game can be run on various smartphone & 4.24 & Very Feasible \\
\hline & Average total score & 4.26 & Very Feasible \\
\hline
\end{tabular}

Source: Data processed with SPSS, 2020.

Table 12. Results of Descriptive Statistics Test on Display Aspect

\begin{tabular}{clcc}
\hline No. & \multicolumn{1}{c}{ Display Aspect } & Average Score & Qualification \\
\hline 1 & The game display is attractive & 4.51 & Very Feasible \\
2 & The image is clear and has a proportional size & 4.32 & Very Feasible \\
3 & The writing can be read clearly & 4.48 & Very Feasible \\
4 & The sound effects and music used are interesting & 4.33 & Very Feasible \\
& The face mesh effect (smoother facial skin) is & 4.13 & Feasible \\
& useful & $\mathbf{4 . 3 5}$ & Very Feasible \\
\hline
\end{tabular}

Source: Data processed with SPSS, 2020.

Based on the data in Table 12, it can be concluded that in terms of display, this Instagram filterbased game can be qualified as 'very feasible' to use. Of the four statements, only statement number 5 received a qualification due to an average score of 4.13. For some users, a face mesh effect or an effect that can make facial skin smooth is less useful, especially for male respondents. Based on these data, male respondents' answers to this statement varied; two respondents gave a value of 1 or disagree, three respondents gave a value of 2 or slightly agree, four respondents gave a value of 3 or undecided, five respondents gave a value of 4 or agree, and the rest, 23 respondents, gave a value of 5 or strongly agree. However, this face mesh is still favored by the majority of the users, especially female users.

Table 13. Results of Descriptive Statistics Test on Learning Design Aspect

\begin{tabular}{|c|c|c|c|}
\hline No. & Learning Design Aspect & Average Score & Qualification \\
\hline 1 & The language used is communicative & 4.41 & Very Feasible \\
\hline 2 & $\begin{array}{l}\text { The language used is in accordance with the } \\
\text { student competence }\end{array}$ & 4.48 & Very Feasible \\
\hline 3 & $\begin{array}{l}\text { The questions are in accordance with financial } \\
\text { accounting } 1 \text { learning material, which is the } \\
\text { double-entry system (Dr. and Cr.) }\end{array}$ & 4.45 & Very Feasible \\
\hline 4 & Questions are presented clearly and interestingly & 4.36 & Very Feasible \\
\hline
\end{tabular}


Source: Data processed with SPSS, 2020.

Based on the data in Table 13, it can be concluded that from the aspect of learning design, this Instagram filter-based game can be qualified as very feasible with an average total score of 4.43. The learning process through educational game is not only related to the game but also must pay attention to the scope of the material in the game. The learning design aspect of this game is assessed in terms of the language used, which must be communicative and in accordance with international standard competencies; and the questions must be in accordance with the RPS of financial accounting 1 course and presented clearly and interestingly, and finally from these two perspectives this game is stated to be very feasible by users. This means that users also strongly agree that this Instagram filter-based educational game can assist them in learning accounting material that is in accordance with the learning objectives in the course RPS.

Table 14. Results of Descriptive Statistics Test on Accounting Learning Motivation Aspect

\begin{tabular}{|c|c|c|c|}
\hline No. & Accounting Learning Motivation Aspect & Average Score & Qualification \\
\hline 1 & This game makes me interested to play it again & 4.48 & Very High \\
\hline 2 & This game makes me happy to learn accounting & 4.49 & Very High \\
\hline 3 & $\begin{array}{l}\text { This game makes me more interested in learning } \\
\text { an accounting material }\end{array}$ & 4.46 & Very High \\
\hline 4 & $\begin{array}{c}\text { This game motivates me to study accounting } \\
\text { Average total score }\end{array}$ & $\begin{array}{l}4.49 \\
\mathbf{4 . 4 8}\end{array}$ & $\begin{array}{l}\text { Very High } \\
\text { Very High }\end{array}$ \\
\hline
\end{tabular}

Source: Data processed with SPSS, 2020

Based on the data in Table 14, it can be concluded that from the aspect of motivation to learn accounting, this Instagram filter-based game can be qualified as 'very feasible' with an average total score of 4.48. These results show that accounting students are happy with the existence of an accounting learning media with an interesting and fun system like this Instagram filter-based accounting educational game.

Analysis of the results of respondents 'answers to the statement one about students' interest in playing this game resulted an average score of 4.48 , which means that they are very interested and want to continue to try this educational game. Students' interest in trying this game again will encourage them to know more about the material discussed in the game. This is further confirmed by the answers to statements number two and three, which state that through this game students are increasingly happy to learn accounting and become more interested in learning an accounting material. Statements number two and three each got an average score of 4.49 and 4.46 , or 'very high.'

Furthermore, the final statement from the aspect of learning motivation, namely whether students are motivated to study Accounting, get a mean score of 4.49 or 'very high'. Based on the results of the descriptive statistical test, it can be concluded that students are more motivated to learn accounting through this Instagram filter-based accounting educational game. An interesting accounting learning media is needed in the learning process of accounting courses so as to create a pleasant learning atmosphere that is expected to arouse student learning motivation.

Daily statistical data released by the Spark AR application about the use of Instagram filters with the title "Debit-Credit" shows a significant figure. According to statistics released as of 
June $10^{\text {th }}, 2020$, this Instagram filter had been displayed on users' screen 51,542 times; users had taken this filter's picture or video using the Instagram camera 5.570 times; users had shared this Instagram filter 369 times. Although this Instagram filter is specifically for users who understand accounting material, Spark AR statistics shows that many people or Instagram users who are mostly at the age of college students, i.e. 18-24 years old, are interested in learning accounting in a more fun way.

\section{Conclusion and Suggestion}

Based on the results of research and discussion, the following conclusions can be drawn:

1. The Instagram filter-based accounting educational game as a fun learning media was developed through five stages based on the ADDIE model, namely Analysis, Design, Development, Implementation, and Evaluation. The Instagram filter was created using the Spark AR application.

2. The Instagram filter-based accounting educational game as fun learning media declared feasible by the experts who assessed the material and information technology aspects. The average total score of the validation results from the material expert is 4.71 or in the 'very feasible' category. The results of the validation from information technology expert also indicated 'very feasible' category with an average total score of 4.35.

3. Student interest is very high towards Instagram filter-based accounting educational game as afun learning media as indicated by the average score of 4.48 in the learning motivation aspect.

4. With an educational game based on an Instagram filter as a fun learning media, students motivation to study accounting becomes higher. This conclusion is based on the average total score on the aspect of accounting learning motivation, i.e. 4.48 or 'very high'.

Based on the results and discussion as well as the research conclusions, the author proposes the following suggestions:

1. Accounting lecturers should have behavioral changes in adapting with various interesting learning media to make the learning process more fun and to increase student interest in learning accounting and ultimately, improving their understanding in accounting subject.

2. Future researchers may develop an Instagram filter-based accounting educational game for other accounting materials, such as merchandising and manufacturing companies.

3. Future researchers may develop other variations of the Instagram-based accounting educational game in addition to the 'debit or credit' answers, such as guessing accounting journal entries.

\section{References}

Amy, Y. C. M., Carter, S., \& Shuo, K. Z. (2019). Leadership, contribution, language and shared content as metrics in Malaysian millennials'decision making. Journal of Business and Finance in Emerging Markets, 2(2), 153-162.

Calabor, M., Mora, A., \& Moya, S. (2019). The future of 'serious games' in accounting education: A Delphi study. Journal of Accounting Education,46(4), 43-52.

Carmigniani, J., Furht, B., Anisetti, M., Ceravolo, P., Damiani, E., \& Ivkovic, M. (2011). Augmented reality technologies, systems and applications. Multimedia tools and applications, 51(1), 341-377.

Charsky, D., \& Ressler, W. (2010). "Games are made for fun": Lessons on the effects of concept maps in the classroom use of computer games. Computers and Education, 56(3), 604-615.

Duarte, F. (2019, September 9). How many times that was spended by Indonesian on Social Media? BBC News Indonesia. Retrieved from https://www.bbc.com/ 
Hikmah, N., \& Mustikawati, I. (2017). The Development of Accounting Uno Card Game as an Accounting Learning Media. Kajian Pendidikan Akuntansi Indonesia, 4(1), 1-10.

Is This The Number of Instagram Users in Indonesia? (2019, December 12). Kompas.com. Retrieved from https://tekno.kompas.com/

Li, J., Ma, S., \& Ma, L. (2012). The Study on the Effect of Educational Games for the Development of Students' Logic-Mathematics of Multiple Intelligence. Physics Procedia,33, 1749-1752.

Mardikaningrum, K., Supriyadi, S., \& Sudiyanto. (2017). The Need of Learning Media Arts in Junior High School (Study on Grade VII Students of Junior High School Negeri 1 Mojolaban). Proceeding of $2^{\text {nd }}$ International Conference of Arts Language and Culture, Surakarta, 323-327.

Molenda, M. (2003). In search of the elusive ADDIE model. Performance Improvement, 42(5), 34-36.

Pelana, R. (2014). Fun Learning Management for Physical Education, Sport and Health. Asian Social Science, 10(5), 85-90.

Pincus, K., Stout, D., Sorensen J., Stocks, K., \& Lawson, R. (2017). Forces for change in higher education and implications for the accounting academy. Journal of Accounting Education,40, 1-18.

Pratiwi, A., \& Sagoro, E. (2017). Development Game Accounting Based on RPG Maker as Accounting Learning Media Accounting Students Class X. Kajian Pendidikan Akuntansi Indonesia, 3(1), 1-11.

Ramadhan, B. (2020, February 3). These are The Data of Internet Users in The World 2020. Teknoia.

Rambli, D., Matcha, W., \& Sulaiman, S. (2013). Fun Learning with AR Alphabet Book for Preschool Children. Procedia Computer Science, 25, 211-219.

Republic of Indonesia. (2005). Act No. 14 about Lecturers. Indonesia.

Saputri, A., Sukirno, S., Kurniawan, H.,\&Probowasito, T. (2020). Developing Android GameBased Learning Media "Go Accounting" in Accounting Learning. Indonesian Journal on Learning and Advanced Education (IJOLAE), 2(2), 91-99.

Seow, P., \& Wong, S. (2016). Using a mobile gaming app to enhance accounting education. Journal of Education for Business, 91(8), 434-439.

Sheldon, P.,\& Bryant, K. (2016). Instagram: Motives for its use and relationship to narcissism and contextual age. Computers in Human Behavior, 58, 89-97.

Sugiyono. (2017). Qualitative, Quantitative, and R\&D Research Method. Bandung: Alfabeta.

Sunyoto, D. (2016). Accounting Research Method. Bandung: PT. RefikaAditama.

Ting, H., Ming, W., Run, E.,\& Choo, S. (2015, January). Beliefs about the Use of Instagram: An Exlploratory Study.International Journal of Business and Innovation, 2(2), 15-31.

Utami, Y., Wahyu, A., Clara, S.,\&Putri, Y. (2019). Accounting Game Education as The Student Motivation Improvement Media (Study Case : SMK Negeri 8 Bandar Lampung). Jurnal TEKNOKOMPAK, 13(2), 16-23.

Vlachopoulos, D.,\&Makri, A. (2017, July 10).The effect of games and simulations on higher education: A systematic literature review. International Journal of Educational Technology in Higher Education, 14(22).

Vandercruysse, S., Vandewaetere, M., \& Clarebout, G. (2012). Game-based learning: A review on the effectiveness of educational games. Handbook of Research on Serious Games as Educational, Business and Research Tools, 628-647.

Warren, Carl, S,. Reeve, James, M.,\&Duchac, Jonathan, E. (2009). Accounting, $23^{\text {rd }}$ ed. USA: LEAP Publishing Services, Inc. 
Weygandt, Jerry, J., Kimmel, Paul, D.,\&Kieso, Donald, E. (2015). Accounting Principles, $12^{\text {th }}$ ed.USA: John Wiley \& Sons, Inc.

Yana, E., Komara, A.,\&Anisah, A. (2019). Development of Games Educative Based on Android as The Accounting Learning Media to Improve Student Analysis Ability. Jurnal Akuntansi dan Pendidikan (ASSETS), 8(2), 157-173. 